Piotr Chlebowicz

\title{
PRZESTĘPCZOŚĆ STADIONOWA JAKO NOWY OBSZAR BADAŃ KRYMINOLOGICZNYCH
}

W dyskusjach naukowych dotyczących zarówno kondycji polskiego środowiska kryminologicznego, jak również wyników badawczych osiąganych przez krajową kryminologię, wielokrotnie podkreślano, że wymieniony obszar naukowy dotknięty jest znacznym stopniem dezintegracji. ${ }^{1}$ Kwestia ta była również podnoszona podczas Ogólnopolskiego Zjazdu Katedr Prawa Karnego w Szklarskiej Porębie w 2008 r. Wybitni przedstawiciele nauk kryminologicznych w osobach prof. M. Melezini (UwB) i prof. K. Krajewskiego (UJ) zwrócili wówczas uwagę na liczne zaniedbania w zakresie badań kryminologicznych. Wydaje się, że jest to istotne przynajmniej z dwóch zasadniczych powodów.

Po pierwsze, skuteczne prowadzenie polityki kryminalnej wymaga od agend formalnej kontroli społecznej posiadania kompleksowej wiedzy odnośnie do zjawisk, które ustawodawca uznał za niepożądane. Tymczasem obserwujemy, iż kluczowe decyzje politycznokryminalne podejmowane są w swoistej kryminologicznej próżni. ${ }^{2}$ Przedsięwzięcia kryminalizacyjne w przeważającej większości przypadków pozbawione są naukowego uzasadnienia, w związku z czym można powiedzieć, iż podejmowane są niejako poza kontekstem naukowym. ${ }^{3}$ Warto jednak zauważyć, że problem ten dotyczy nie tylko Polski, lecz także innych krajów zachodniej Europy.

Wydaje się, że wciąż aktualne pozostają wnioski dyskusji dotyczące polskiej kryminologii, w tym także uwagi D. Wójcik, która zauważyła, iż polskie ośrodki kryminologiczne są zbyt mało zróżnicowane, nie lansują jakiegoś określonego kierunku w zakresie teorii czy empirii, nie ma właściwie szkół kryminologicznych. Za mało jest dyskusji i polemik naukowych. Środowisko kryminologiczne jest mało zintegrowane. Zob. szerzej wypowiedź D. Wójcik, Aktualny stan i perspektywy rozwojowe kryminologii. Konferencja Kryminologów Polskich, Warszawa, 25 stycznia 1990 r., Przegląd Prawa Karnego 1990, t. 5, s. 73 i n. Obserwuje się jednak próby zmiany tej niekorzystnej tendencji. W związku z tym należy podkreślić, iż jednym z celów inicjatywy powołania Forum Naukowego Podlasie - Warmia i Mazury jest integracja środowisk naukowych w obszarze nauk penalnych, w szczególności w zakresie kryminologii.

2 Ponadto można odnotować stanowisko L. Morawskiego, który zauważył, iż w dobie prawa interwencjonistycznego udział w procedurach prawodawczych różnego rodzaju ekspertów, doradców naukowo-technicznych, komisji i komitetów badawczych stał się nie tylko czymś naturalnym, lecz nieodzownym. Zob. szerzej L. Morawski, Główne problemy współczesnej filozofii prawa. Prawo w toku przemian, Warszawa 1999, s. 46.

3 W tym miejscu warto odnieść się do opinii L. Gardockiego, który trafnie podniósł, iż główne znaczenie postulatu naukowości procesu kryminalizacji polega więc na zmiejszeniu zakresu swobody ustawodawcy, na pewnym zracjonalizowaniu i utrudnieniu tego procesu. Zob. szerzej tenże, Zagadnienia teorii kryminalizacji, Warszawa 1990, s. 106. 
Jest to nowy trend politycznokryminalny ściśle związany z uwikłaniem prawa karnego w bieżące konflikty polityczne, określany mianem tzw. populizmu penalnego. Można tutaj wskazać przykład wprowadzenia do polskiego systemu prawa karnego instytucji chuligańskiego występku i trybu przyśpieszonego, który okazał się legislacyjnym niewypałem. Wątek ten zostanie rozwinięty w dalszej części niniejszego artykułu.

Po drugie, dotychczasowy dorobek nauk penalnych uzasadnia twierdzenie, że przestępczość XX i XXI wieku cechuje się ogromną dynamiką zarówno w zakresie przekształceń jej form i postaci, jak jej rozmiarów i przejawów. Wystarczy porównać klasyczną przestępczość z użyciem przemocy z nowymi, skomplikowanymi formami, takimi jak na przykład handel ludźmi, zorganizowana przestępczość gospodarcza, przestępstwa giełdowe. Wielowymiarowość rzeczywistości kryminalnej ${ }^{4}$ wymaga zatem od nauk penalnych ciągłego rozwoju. W tym stanie rzeczy należy stwierdzić, iż wyniki badań kryminologicznych ${ }^{5}$ mają ograniczoną przydatność, dlatego też należy je regularnie aktualizować. Trzeba bowiem niestety przyznać, że przestarzała wiedza staje się bezużytecznym balastem. Odrębną kwestią pozostaje metodologia opisywanych wyżej badań. ${ }^{6}$ Interdyscyplinarność kryminologii przy jednoczesnym coraz bardziej złożonym przedmiocie badań wymaga także znacznych modyfikacji instrumentarium badawczego.

W latach 2004-2007 w Zakładzie Kryminologii, Wiktymologii i Problematyki Przestępczości Zorganizowanej Wydziału Prawa i Administracji UWM w Olsztynie przeprowadzany był program badawczy ${ }^{7}$, którego przedmiotem było zjawisko przemocy występującej w kontekście piłki nożnej - określane mianem przestępczości lub chuligaństwa stadionowego. Poniżej zostaną przedstawione jego najważniejsze wyniki, na podstawie których udało się częściowo zrekonstruować obraz wymienionego wyżej sektora przestępczości.

4 Jak podnosi J. Błachut, rzeczywistość kryminalna, która jest tworzona poprzez zbiory jednostek (przestępcy, a także ofiary), zachowania (czyny będace przestępstwami w rozumieniu prawa karnego), normy prawa karnego i agendy sformalizowanej kontroli prawnej analogicznie do rzeczywistości społecznej, cechuje się zmiennością i dynamika. Dlatego też badacz w zależności od określonych potrzeb badawczych może być zorientowany na różne wymiary tej rzeczywistości. Poznanie każdego z nich jest możliwe i równie zasadne. Zob. szerzej J. Błachut, Problemy związane z pomiarem przestępczości, Warszawa 2007, s. 36.

$5 \quad$ W tym kontekście należy zastanowić się nad postulatami twórcy polskiej szkoły kryminologii S. Batawii, który protestował przeciwko globalnemu traktowaniu sprawców różnego rodzaju przestępstw, tak jakby tworzyli oni jednolitą kategorię. Oznacza to, że kryminologia powinna badać poszczególne kategorie przestępstw. Wydaje się, że uwaga ta dotyczy również nowych zjawisk patologicznych. Zob. szerzej S. Batawia, Wstęp do nauki o przestępcy. Zagadnienie skłonności przestępczych, Wrocław 1984 r.

6 Zob. szerzej E.W. Pływaczewski, Nowe kierunki badań kryminologicznych i ich znaczenie w strategii bezpieczeństwa narodowego, (w:) K. Krajewski (red.), Nauki penalne wobec problemów współczesnej przestępczości. Księga jubileuszowa z okazjji 70. rocznicy urodzin Profesora Andrzeja Gaberle, Warszawa 2007, s. 495 i n.

$7 \quad$ W tym miejscu warto podkreślić, że zasięg programu obejmował praktycznie cały obszar kraju. Zastosowano metody badawcze, takie jak: badania aktowe, zasoby informacyjne Policji (pismo KGP, Główny Sztab Policji o sygn GS -o- 586/05/JSz, decyzja nr 165 Ministra Spraw Wewnętrznych i Administracji z dni 28. 12. 2005), wywiady swobodne z funkcjonariuszami Policji, działaczami sportowymi, monitoring Internetu, literatura przedmiotu. 
Rozważania muszą zostać poprzedzone wstępnymi uwagami dotyczącymi problemów definicyjnych. Jak wiadomo, wprowadzenie chuligańskiego charakteru występku czynu wraz z trybem tzw. sądów 24-godzinnych jako instrumentów zwalczania przestępczości stadionowej, zakończyło się kompletnym fiaskiem. Tryb przyśpieszony, mający być skutecznym narzędziem zwalczania chuligaństwa, jest obecnie stosowany niemal wyłącznie do walki z pijanymi kierowcami. ${ }^{8}$ Również reaktywowanie kontrowersyjnej konstrukcji karnomaterialnej w postaci chuligańskiego charakteru występku trudno uznać za trafny manewr politycznokryminalny. Warto w związku z tym zauważyć, że już na etapie prac legislacyjnych podnoszono, że uzasadnienie projektu było wewnętrznie sprzeczne, gdyż jego autorzy z jednej strony twierdzili, że wzrasta liczba przestępstw o charakterze chuligańskim, z drugiej zaś strony argumentowali, że brak jest danych statystycznych dotyczących tych właśnie przestępstw. ${ }^{9}$ Autorzy projektu przeoczyli jednak fakt, że KGP prowadzi statystyki ekscesów chuligańskich i masowych zakłóceń porządku publicznego podczas imprez masowych, z których wynikało, że liczba tych zdarzeń spada. ${ }^{10} \mathrm{Na}$ marginesie należy odnotować, że nie uwzględniono opinii Komisji Kodyfikacyjnej Prawa Karnego z dnia 19.12.2005 r. o projekcie zmiany prawa karnego, która jednoznacznie określiła, że przesłanki kryminologiczne i kryminalnopolityczne tkwiące u podstaw instytucji chuligańskiego charakteru przestępstwa są niejasne. ${ }^{11}$

Przedstawiona powyżej argumentacja wystarczająco uzasadnia konieczność prowadzenia badań w zakresie nowych zjawisk kryminologicznych. Abstrahując od politycznego kontekstu działań ustawodawczych w zakresie normatywnych aspektów omawianych regulacji, należy zauważyć, że przecież problem przemocy powiązanej z widowiskami sportowymi jest realny. W literaturze przedmiotu zwracano uwagę, że pomimo trudnego do zaakceptowania określenia chuligaństwa ${ }^{12}$, pojęcie to łączy się jednak z aktami przemocy popełnianymi w związku z meczami piłki

P. Wiliński, Postępowanie przyśpieszone - tzw. sądy 24-godzinne, (w:) Kryminalistyka i nauki penalne wobec przestępczości. Księga pamiątkowa dedykowana Profesorowi Mirosławowi Owocowi, red. H. Kołecki, Poznań 2008, s. 92. Ponadto P. Wiliński zauważa, iż wbrew oczekiwaniom społecznym postępowanie to trwać może znacznie dłużej niż zapowiadane i obiecane 24 godziny. Analiza przepisów wskazuje, iż w skrajnych przypadkach całość może trwać nawet do 2 miesięcy (48 godzin do wniesienia wniosku do sądu, 14 dnia na postępowanie w pierwszej instancji, ewentualna 14-dniowa przerwa, 3 dni na złożenie wniosku o uzasadnienie, kolejne 3 dni na jego sporządzenie, 7 dni na wniesienie apelacji, wreszcie do 30 dni dla wydania wyroku przez sąd drugiej instancji). Tym samym z równym powodzeniem sądy 24 -godzinne określać możemy mianem sądów 60 -dniowych albo 1440-godzinnych, Tamże, s. 95.

9 W. Wróbel, Spór o „dostateczny poziom represyjności” prawa karnego w płaszczyźnie legsislacyjnej, (w:) Represyjność polskiego prawa karnego, red. A. Szwarc, Poznań 2008, s. 17.

10 Tamże, s. 17

11 Zob. szerzej, Opinia..., Państwo i Prawo 2006, s. 95 i n.

12 Na przykład warto wskazać opinię A. Marka, który przy okazji omawiania historycznych korzeni instytucji chuligańskiego charakteru czynu w polskim prawie karnym podniósł, że: Bez obawy pomyłki można stwierdzić, że chodziło nie tylko o zaostrzenie karalności wybryków chuligańskich w miejscach publicznych (...), lecz także o uzyskanie sprawnego narzędzia represji wobec sprawców ataków na funkcjonariuszy milicji obywatelskiej (..), narzędzia wykorzystywanego w różnych okresach kryzysów do represjonowania uczestników akcji protestacyjnych przeciwko władzy ludowej. A. Marek, Powrót chuligańskiego charakteru czynu w prawie karnym, (w:) Nauki penalne..., op. cit., s. 99. 
nożnej. ${ }^{13}$ Taka interpretacja jest spotykana przede wszystkim w kryminologii brytyjskiej (football hooliganism). Z drugiej jednak strony można posługiwać się pojęciem przestępczości stadionowej. Wymieniona kategoria kryminologiczna odnosi się do wyodrębnionego zjawiska, którego geneza i niektóre współczesne przejawy ściśle wiążą się z terenem stadionu piłkarskiego i fenomenem kibicowania. $\mathrm{Na}$ obecnym etapie badawczym można chyba przyjąć, iż określenie przestępczość stadionowa ma charakter roboczy.

Wydaje się, że można wyróżnić przynajmniej niektóre konstytutywne cechy współczesnej przestępczości stadionowej. ${ }^{14}$ Należy jednak mieć świadomość, że uzyskanie kompletnego fenomenologicznego obrazu wymienionego segementu przestępczości nie jest łatwe. Poniżej zostaną zaprezentowane hipotezy, które są wymieniane w literaturze przedmiotu, dotyczące najważniejszych przejawów omawianego zjawiska.

1. Mecze piłkarskie stanowią główne okazje do wybuchu konfliktów między kibicami. Akty przemocy zdarzają się także w związku z innymi imprezami sportowymi, ale w porównaniu do meczów piłkarskich ich rozmiary i następstwa są niewielkie.

2. Mają miejsce gwałtowne starcia między grupami kibiców, w których dużą rolę odgrywa planowanie i chęć walki z użyciem przemocy.

3. Występuje brak wyraźnych ,wyzwalaczy przemocy” - ekscesy mają miejsce niezależnie od wyniku meczy, dochodzi do nich zarówno przed, w trakcie jak i po meczu, poza terenem stadionu.

4. Wokół zjawiska przemocy na stadionach piłkarskich formuje się subkultura, z wyraźnym podziałem na grupy należące do określonych klubów piłkarskich.

5. Znaczącą rolę w genezie aktów przemocy odgrywa alkohol.

6. W środowiskach chuligańskich zyskuje znaczenie ideologia prawicowa i ekstremistyczna, która wpływa na rozwój postaw rasistowskich.

7. W niektórych przypadkach przemoc ma charakter transgraniczny, przy czym zdarzają się sytuacje, gdy konflikt dotyczy jednego europejskiego, kra-

\footnotetext{
13 Zob. zwłaszcza S. Frosdick, P. Marsh, Football Hooliganism, Portland 2005; P. Chlebowicz, Przestępczość stadionowa. Kontrowersje wokół definicji i oceny zjawiska (w:) Wybrane zagadnienia kryminologii, red. W. Pływaczewski, Olsztyn 2007, s. 60 i n.

14 W literaturze przedmiotu spotkać można pogląd, iż kryminologiczna charakterystyka tego zjawiska zawiera następujące punkty: 1. Zachowania kwalifikowane jako przestępstwa lub wykroczenia popełniane są w przeważającej większości przy użyciu przemocy. 2. Sprawcy tych przestępstw wykazują swoistą motywację. 3 . Są to przestępstwa popełniane $z$ reguły w grupie (grupowy charakter działania). 4. Przestępstwa te maja związek z wydarzeniami sportowymi, w szczególności z meczami piłki nożnej. Zob. P. Chlebowicz, tamże, s. 68.
} 
ju, wówczas pojawiają sie cechy migracji (odnosi się do fanów z różnych miast). ${ }^{15}$

Na podstawie zaprezentowanego wyżej zestawienia można powiedzieć, że jednym z najważniejszych wyznaczników przestępczości stadionowej są niewątpliwie zachowania kwalifikowane jako przestępstwa lub wykroczenia, które popełniane są w przeważającej większości z użyciem przemocy. W tym ujęciu przestępczość stadionowa stanowiłaby kolejną odmianę przestępczości agresywnej. Teza ta jest uzasadniona najnowszymi wynikami badań przeprowadzonych w Cambridge. ${ }^{16}$ Okazało się, iż sylwetka stadionowego chuligana wykazuje wyraźne podobieństwo do profilu sprawców przestępstw agresywnych. Jak zauważa B. Hołyst „,na 62 takie przypadki przypadły aż 53 (85\%) czyny przestępcze z użyciem przemocy. (...) wśród 82 przestępców używajacych przemocy znalazło się 53 (65\%) dopuszczajacych się chuligaństwa futbolowego."17

W związku z powyższym należy jednak odnotować, że przemoc stosowana przez stadionowych chuliganów posiada wiele odmian, inne są również cele i okoliczności, w których dochodzi do manifestowania przemocy. Grosso modo można wyróżnić przemoc stosowaną w obrębie stadionu zazwyczaj w związku z meczem piłkarskim oraz przemoc stosowaną poza kontekstem sportowym. W pierwszym przypadku należy uwzględnić rolę czynników sytuacyjnych ${ }^{18}$, w szczególności zaś funkcjonowanie mechanizmów psychologii tłumu. Zauważa się, że w następstwie zachodzących w obrębie tłumu procesów grupowych u jednostek tworzących określone zbiorowisko występują takie zjawiska, jak na przykład: czasowa utrata samoświadomości, zanik poczucia własnej odrębności i większej niż zazwyczaj skłonności do angażowania się w działalność dewiacyjną. ${ }^{19}$ Właściwie większość teorii opisujących zachowania zbiorowe (teoria zarazy ${ }^{20}$, konwergencyjna, normatywna, teoria wartości towarzyszących) inspirowana była w znacznej mierze pracami Le Bona (który posługiwał się m.in. pojęciem tłumu zbrodniczego). Warto również zauważyć, że zagadnienie przestępności zgromadzeń było przedmiotem zainteresowań badawczych samego Lombrosa, który zauważył, iż ,przyłączenie się jednost-

15 Zaprezentowana lista cech przestępczości stadionowej została skonstruowana przez B. Hołysta, tenże, Socjologia kryminalistyczna. Tom 2, Warszawa 2007, s. 430.

16 Badaniami objęto grupę 411 osób w wieku 8-48 lat. Zobacz szerz. D.P. Farrington, Comparing football hooligans and violent offenders: Childhood, adolescent, teenage and adult features, Monatsschrift fuer Kriminologie und Strafrechtsreform 2006, nr 3, s. 193 i n.

17 B. Hołyst, Socjologia kryminalistyczna. Tom 1, Warszawa 2007, s. 545.

18 Wydaje się, że chodzi przede wszystkim o konstelację różnorodnych czynników związanych z przebiegiem meczu (incydenty na polu gry, błędy sędziego, animozje kibiców, atmosfera meczu), kwestie dotyczące poziomu zabezpieczenia obiektu (infrastruktura bezpieczeństwa, profesjonalizm służby ochrony organizatorów meczu).

19 Zob. szerzej P. Piotrowski, Psychologiczne uwarunkowania zachowań zbiorowych (w:) Przemoc i marginalizacja. Patologia dyskursu społecznego, red. P. Piotrowski, Warszawa 2004, s. 145.

20 Jak podaje $\mathrm{S}$. Wanat (...) jednostka znajdująca się $\mathrm{w}$ anonimowym tłumie podlega procesom wzajemnej stymulacji bądź znajduje się w stanie hipnotycznego podniecenia, które wymusza określone odczucia, bodźce oraz działania. Wskutek tego zachowania jednostek znajdujących się w tłumie, generowane są przez to, co nazywamy instynktem stada. Tenże, Naruszenia porządku towarzyszące imprezom sportowym - aspekty socjologiczne, (w:) Naruszenia porządku towarzyszące imprezom sportowym, red. A.J. Szwarc, Poznań 1995, s. 72 i n. 
ki do tłumu zmienia jej indywidualność, każdy uczestnik tłumu staje się zdolnym do spełnienia takich przestępstw, o jakich będąc pojedynczo, nie miałby odwagi pomyśleć". ${ }^{21}$ Problem etiologii przemocy stadionowej można sprowadzić do pytania: w jakim stopniu nienawiść i agresja są efektem wyładowanej frustracji ${ }^{22}$, której

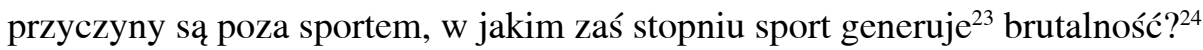

Jak już wyżej zaznaczono, przemoc stosowana przez chuliganów przejawia się również poza terenem obiektu sportowego. Paradoksalnie bowiem stadiony przestają być miejscami, które stanowią główny i podstawowy obszar działania. Skuteczna reakcja agend sformalizowanej kontroli społecznej spowodowała zjawisko wypierania (displacement) chuligaństwa ze stadionów. ${ }^{25}$ Stąd też w brytyjskiej literaturze sformułowano tezę, iż chuligaństwo w swej klasycznej postaci stopniowo obumiera. ${ }^{26}$ Dostrzega się ponadto, iż istota przemocy futbolowej (football - related violence) ulega przekształceniom, co znacząco wpływa na formy i zakres przestępczych zachowań. Początkowe stadium polegało na sporadycznym używaniu przemocy w obrębie stadionu, kierowanej przede wszystkim wobec sędziów i zawodników. Kolejna faza obejmowała już wyraźny wzrost agresji pomiędzy grupami fanów, a także pomiędzy kibicami i Policją, wciąż jednak ograniczonej do terenu stadionu. Trzecie stadium rozwojowe wykracza poza obiekt sportowy. Przejawy charakterystyczne dla tej fazy to bójki angażujące znaczną ilość uczestników (pseudokibiców), „zasadzki” na dworcach kolejowych, drobne kradzieże, akty wandalizmu i coraz poważniejsze starcia z Policją. Podkreśla się tutaj zwłaszcza zanik kontekstu sportowego (mecz lub jego wynik nie stanowi już uzasadnienia dla przemocy), a nawet wykształcanie się pewnych form rytuału wojennego. ${ }^{27}$

Zarysowany wyżej model rozwojowy (Stages of Development) stanowi dogodny punkt odniesienia, gdyż podobne procesy dostrzec można także w przypadku polskiej odmiany przestępczości stadionowej. W tym miejscu należy zauważyć, iż w związku z przestępną aktywnością chuliganów poza stadionem wyodrębniły się

21 B. Wróblewski, Przestępstwa tłumu, Wilno 1922, s. 57.

22 Na przykład S.Hall i J. Clark w swych pracach kładli silny nacisk na bliskie związi pomiędzy kibicami a ich zespołem. Przemoc podczas meczy była spowodowana przez infiltrators - młodych mężczyzn, którzy nie byli prawdziwymi kibicami, lecz wykorzystywali mecz jako dogodną okazję do zamanifestowania agresywnego stylu życia. Wyżej wymienieni autorzy reprezentowali teorię subkulturowa, w myśl której uczestnictwo w subkulturach umożliwiało rozwiązywanie konfliktów. Źródło agresji tkwiło zatem w warstwie kulturowej, mecz był tylko pretekstem do realizacji podkulturowych wartości. Zob. szerzej S. Frosdick, P. Marsh, op. cit., s. 90 i n.

23 W kryminologii włoskiej zauważa się, że stadion, na którym rozgrywa się mecz, nie stanowi wyłącznie obiektu sportowego. Dla kibiców jest to również przestrzeń symboliczna, gdzie odgrywa się rytuał pomiędzy wrogami. Zachowania kibiców (symboliczne gesty, zniewagi, przyśpiewki) stanowią przecież substytuty fizycznej agresji. Zob. szerzej, tamże, s. 58 i n.

$24 \quad Z$ historycznego punktu widzenia piłka nożna od zarania stanowiła spektakl pełen przemocy. Znamienna jest zwłaszcza opinia pewnego Francuza, który w 1829 r. po obejrzeniu meczu w Derby zapytał: Jeżeli to jest to, co oni nazywają footballem, to co w takim razie nazywają walką? Zob. szerzej S. Frosdick, P. Marsh, op. cit., s. 11.

25 J. Williams, Hooliganism; New Football and Social Policy in England, Eurofan International Conference, Liege, April 22-23, 2002 r., s. 26.

26 Tamże, s. 26 i n.

27 S. Frosdick, P. Marsh, op. cit., s. 69 i n. 
rozmaite strategie i taktyki, które są znacznie bardziej złożone niż modus operandi stosowany na stadionach podczas meczy. ${ }^{28}$ Można zatem wymienić „ustawki”, ,akcje”, ,wjazdy”, ,promocje” oraz akty wandalizmu. ${ }^{29}$ Wydaje się, że wspólną cechą zdarzeń inicjowanych przez pseudokibiców zarówno na terenach obiektów sportowych, jak i poza nimi, jest motywacja. Jest to ciekawe zagadnienie, gdyż - w odróżnieniu od zdecydowanej większości sprawców klasycznych przestępstw „kryminalnych" - chuligani piłkarscy wykazują bardzo specyficzną motywację. Siłę napędową działań pseudokibiców tworzą czynniki motywacyjne ściśle związane z podkulturowymi normami i wartościami nieformalnych grup. Istotny jest zwłaszcza prestiż utożsamiany z potrzebą obrony barw klubowych. Należy przy tym uwzględnić, że ewolucja chuligaństwa stadionowego objęła także procesy motywacyjne chuliganów - formowanie się grup chuligańskich, które zaczęły się wewnętrznie konsolidować, co sprawiło, iż coraz częściej zaczyna współwystępować motyw ekonomiczny. W związku z powyższym należy zauważyć, iż w literaturze kryminologicznej, obok klasycznych form przestępczości zorganizowanej o charakterze kryminalnym i politycznym, wyróżnia się jeszcze zorganizowaną przestępczość hedonistyczną. Jej istota polega na uprawianiu działalności zakazanej przez prawo, lecz dostarczającej jej uczestnikom satysfakcji lub rozrywki. ${ }^{30}$ Wydaje się, iż określone elementy hedonistyczne występują również w działalności pseudokibiców - wiąże się to z motywacjami członków bojówek, którzy doświadczają podczas np. ustawek silnych bodźców emocjonalnych. Koresponduje to z ustaleniami J.H. Kerra, który interpretował niektóre zachowania pseudokibiców w kategoriach psychopatologicznych. Jego zdaniem chuligani piłkarscy poszukują emocji, a zatem popełnianie futbolowych przestępstw pełni istotną funkcję psychologiczną, polegajacą na przerwaniu dolegliwych stanów emocjonalnych (nudy i rutyny). ${ }^{31}$

W ten sposób wyłania się kolejna równie interesująca kwestia dotycząca form organizacyjnych pseudokibiców. Element ten łączy się ściśle z grupowym charakterem działania. Jak wiadomo, w praktyce nie występuje sytuacja polegająca na tym, iż pojedynczy chuligan dopuszcza się zamachu na osobę lub mienie. Kolektywny modus operandi może przybierać rozmaite postacie. $\mathrm{Z}$ jednej strony mamy do czynienia $\mathrm{z}$ przestępstwami tłumu, z drugiej zaś z określonymi strukturami organizacyjnymi pseudokibiców. Nie ulega wątpliwości, że właściwość przestępczości sta-

W omawianym przypadku w grę wchodzą przede wszystkim zdarzenia określane najczęściej jako zakłócenia lub naruszenia porządku publicznego. Na podstawie danych Komendy Głównej Policji zbiorowe zakłócenia porządku publicznego (oprócz wymienionej kategorii występują także tzw. ekscesy chuligańskie, przy czym jest to terminologia stosowana na potrzeby sprawozdawcze Policji) przybierają dwie postacie: wtargnięcia na boisko lub wtargnięcie po sforsowaniu zabezpieczeń. Wbrew obiegowym opiniom poziom niebezpieczeństwa zdarzeń na stadionach jest o wiele niższy niż przestępne akcje pseudokibiców poza obiektem sportowym. Zob. szerzej P. Chlebowicz, Chuligaństwo stadionowe. Studium kryminologiczne, Warszawa 2009, s. 146.

P. Chlebowicz, Przestępczość stadionowa z perspektywy kryminologicznej, Policja 2008, nr 4, s. 58 wraz z cytowaną tam literatura. 
dionowej, polegająca na ewoluowaniu w kierunku przestępczości zorganizowanej, przesądza o jej dużym potencjale kryminogennym. Jest to trend ogólnoeuropejski. Ilustruje to przykład rozwiązań w Szwajcarii, gdzie chuligaństwo stadionowe potraktowano na równi z przestępczością zorganizowaną, praniem brudnych pieniędzy i terroryzmem. ${ }^{32} \mathrm{~W}$ literaturze przedmiotu zwraca się uwagę, że wyróżnić można trzy aspekty tego zagadnienia. Niektóre z grup pseudokibiców mieszczą się w normatywnej kategorii zorganizowanej grupy przestępczej z art. 258 kk., inne kooperują z takimi grupami ${ }^{33}$, last but not least trzecia kategoria obejmuje relacje ${ }^{34}$, które z uwagi na brak szczegółowych danych trudno jednoznacznie zaklasyfikować. ${ }^{35}$

W świetle przeprowadzonych badań należy w szczegóności zwrócić uwagę na dynamiczny wymiar analizowanego zjawiska. Uzyskane wyniki wskazują bowiem, iż pewna część środowisk pseudokibiców, którzy swe przestępcze kariery rozpoczynali od bójek na stadionach, uległa głębokim przekształceniom. Efektem opisywanego procesu rozwojowego było powstanie grup pseudokibiców, które coraz wyraźniej zaczęły upodabniać się do struktur charakterystycznych dla przestępczości zorganizowanej. Wydaje się przy tym, że istotną fazą tej ewolucji było pojawienie się tzw. bojówki kibicowskiej - hybrydalnej struktury, która w zależności od lokalnego kontekstu stanowiła bądź zorganizowaną grupę przestępczą w rozumieniu art. 258 kk., bądź też grupę chuligańską, której głównym obszarem działania pozostawała „ustawka”. W związku z powyższym trzeba przyjąć, iż z tej perspektywy można mówić o swoistej „,profesjonalizacji” chuligaństwa. Tym samym zasadna jest chyba teza, iż model faz rozwojowych chuligaństwa opisany w kryminologii brytyjskiej (Stages of Development) jest też przynajmniej częściowo adekwatny do analizowanego fragmentu polskiej rzeczywistości kryminalnej.

Grupy przestępcze będące przedmiotem analizy wykazują pewne specyficzne cechy, które przesądzają o tym, iż stanowią odrębny fenomen kryminologiczny. Wynika to przede wszystkim z genezy tych właśnie grup. Wspólnym kontekstem powstania i działania wyszczególnionych struktur pseudokibiców jest miejsce,

32 B. Hołyst, op. cit., s. 428

33 W tym miejscu warto wskazać następujaca informację, która przynajmniej pośrednio potwierdza istnienie powiązań o charakterze kooperacyjnym. Dzięki zeznaniom skruszonych przestępców wyszło na jaw, że w 2003 roku grupa szalikowców została wynajęta przez gang żoliborski do ukarania ochroniarzy z dyskoteki Astor w Jeleniej Górze. Bramkarze mieli w długi majowy weekend poturbować awanturującego się w lokalu Roberta R. ps. Rudy. Jarosław Cz. kierujący wówczas gangiem żoliborskim, chciał przypodobać się sojusznikom z Wołomina i obiecał, że zrobi porządek z krewkimi ochroniarzami. Grupę szturmową tworzyli chuligani z bojówek Legii (...). Szalikowcy byli wielokrotnie wykorzystywani do podobnych rozrób (...) łącznikiem między półświatkiem a bojówkarzami szalikowców był Artur K. ps. Karpiu - zadeklarowany kibic, będacy jednocześnie członkiem dwóch gangów, http://wiadomosci.onet.pl z dnia 15 czerwca 2008 r, TVP Info „Szalikowcy Legii współpracowali z mafia.”

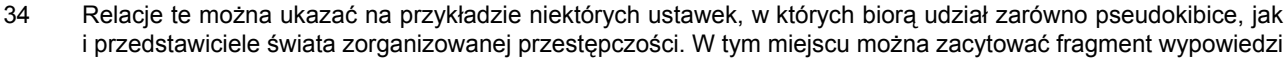
jedengo z bohaterów felietonu Polityki: To nie były jakieś gołodupce, tylko goście przyjeżdżający na walkę swoimi samochodami, mający opłaconych lekarzy (udzielali pomocy rannym i nie zadawali pytań). Wielu z tych gości było żolnierzami gangów, kontrolują panienki, prochy, lewą wódę, przemyt. A ustawki to było ich hobby. I.T. Miecik, Mówimy jak jest, Polityka 2004, nr 29, s. 75.

Tamże, s. 140. 
które miało niewątpliwy wpływ na ich kształt organizacyjny, wartości grupowe, modus operandi a nawet metody rekrutacji nowych członków. Miejscem tym jest oczywiście stadion. Należy jednak przy tym pamiętać, iż obecnie stadion nie stanowi już głównego obszaru działania grup pseudokibiców. Niewątpliwie swoista „ideologia kibicowska", w szczególności prestiż i poczucie silnej identyfikacji z klubem, jest wykorzystywana przez liderów grup pseudokibiców do zawiązywania i umacniania więzi w obrębie grupy. Mechanizm ten ułatwia pozyskiwanie nowych członków zazwyczaj rekrutujących się ze środowisk tzw. ultrasów. ${ }^{36}$ Ekspansja grup pseudokibiców kieruje się na obszary tradycyjnej przestępczości „kryminalnej”, takiej jak przestępstwa przeciwko mieniu, handel narkotykami, przy czym obserwowuje się stopniowy zanik więzi ekscesów chuligańskich z meczami piłki nożnej. Można ponadto mówić o wyraźnych przejawach przestępczości porachunkowej. ${ }^{37}$

Równocześnie trzeba uwzględnić, iż ekspansji tej towarzyszą widoczne zmiany w zakresie struktury organizacyjnej początkowo luźnych grup. ${ }^{38}$ Ponadto wiele danych uzyskanych w trakcie realizacji programu badawczego wskazuje, że niektóre $\mathrm{z}$ tych grup, a także osoby zajmujące wysoką pozycję w nieformalnych strukturach pseudokibiców zaczęły wywierać znaczący wpływ na świat przestępczy w miastach, w których swe siedziby mają konkretne kluby piłkarskie. ${ }^{39}$ Wzmacnia to znacznie hipotezę dotyczacą powiązań tego sektora przestępczości z przestępczością zorganizowaną. Warto w związku z tym ponownie podkreślić, że zaznaczona wyżej kryminogeneza współczesnych postaci przestępczości stadionowej jest charakterystyczna nie tylko dla Polski, lecz także innych krajów europejskich. Marginalizacja stadionu jako podstawowego obszaru działalności, dryfowanie grup pseudokibiców w kierunku przestępczości zorganizowanej, organizowanie konfrontacji w postaci „ustawek” poza obiektami sportowymi to elementy występujące w Wielkiej Brytanii, Holandii, we Włoszech oraz w Niemczech. ${ }^{40}$ Uwzględniając zatem powyższe rozważania, można chyba powiedzieć, że otwiera się nowe pole badań kryminologicznych, które

Rezultaty badań potwierdziły istnienie takiego zjawiska w odniesieniu do grup operujących na terenie Gdańska i Krakowa.

37 Ilustruje to opis następującego zdarzenia: Pod szpital MSWiA w Krakowie podjechały 4 samochody. Wyskoczyło z nich kilkunastu osiłków w barwach Wisły. Pod oknami placówki wykrzykiwali nazwisko zaatkowanego wcześniej mężczyzny, kilku próbowało wedrzeć się do środka.(...) od piątku bezpieczeństwa zaatakowanego mieszkańca Skawiny strzega policjanci .Szymon Jadczak, miasto.gazeta.pl/kraków z dnia 10 kwietnia 2006 r.

Wyjątkowo trudnym zadaniem jest udzielenie odpowiedzi na pytanie dotyczące charakteru wewnętrznych powiązań członków grup przestępczych tworzonych przez chuliganów stadionowych. Niewątpliwie wśród specyficznych dla przestępczości stadionowej czynników, które odgrywają istotną rolę w określaniu hierarchii, należy prestiż, którego zdobycie jest warunkowane aktywnym udziałem w zakłóceniach porządku publicznego i uczestnictwie w „ustawkach”.

39 Rezultaty programu badawczego nie dostarczyły niestety odpowiedzi na pytanie dotyczące relacji pomiędzy stowarzyszeniami kibiców a zarządami klubów. Warto w związku z tym przytoczyć fragment wywiadu z współwłaścicielem Legii Warszawa, Mariuszem Walterem: Mam panu mówić, że chcą nas wykurzyć z Łazienkowskiej? Przecież my wiemy, że Stowarzyszenie Kibiców, z którym zerwaliśmy współpracę, ma mocne wsparcie - mówiąc najoględniej - półświatka. W prasie można było znaleźć sugestie, że popiera ich mafia pruszkowska. (...) Dziś podjęliśmy decyzję o przydzieleniu ochrony osobistej członkom zarządu Legii. Tak to wygląda. Temat jest o wiele głębszy i o wiele bardziej skomplikowany, niż się wydaje. Zob. szerzej, Wywiad Zdzisława Pietrasika z Mariuszem Walterem, Polityka 2007, nr 30, s. 85.

40 Zob. szerzej S. Frosdick, P. Marsh..., op. cit., s. 57 i n. 
obejmuje przede wszystkim zagadnienie gangów pseudokibiców. W związku z powyższym trzeba przyjąć, że niektóre przejawy przestępczości stadionowej należy lokować bezpośrednio w obszarze przestępczości zorganizowanej.

Ważnym aspektem współczesnej przestępczości stadionowej jest rozprzestrzenianie się w środowiskach pseudokibiców ideologii prawicowej, która niewątpliwie wpływa na formowanie się postaw jawnie rasistowskich. Z obserwacji wynika, że europejska wersja rasizmu obecna na stadionach Starego Kontynentu skierowana jest przede wszystkim przeciwko piłkarzom lub kibicom, zazwyczaj imigrantom o innym kolorze skóry, pochodzeniu etnicznym niż większość populacji. Ponadto istnieje zjawisko wzrostu propagandy rasistowskiej i chuligańskiej związane z piłką nożną na stronach internetowych. W Polsce rasizm przybiera niestety najczęściej formę antysemityzmu, który wg M. Kornaka jest już właściwie normą, nieodłącznym elementem większości piłkarskich spotkań. ${ }^{41}$ Znamienne jest to, iż kwestia zachowań rasistowskich stała się przedmiotem odrębnej regulacji - Stały Komitet Europejskiej Konwencji w sprawie przemocy i ekscesów widzów wydał Zalecenie w sprawie zapobiegania rasizmowi, ksenofobii i nietolerancji rasowej w sporcie w 2001 r. ${ }^{42} \mathrm{~W}$ dokumencie tym przyjęto szeroką definicję rasizmu, który obejmuje swym zakresem również ksenofobię, dyskryminację i wszelkie formy nietolerancji rasowej i etnicznej. Z kryminologicznej perspektywy można rozpatrywać akty przemocy i przypadki werbalnej agresji wypływające z rasistowskich pobudek w kategoriach tzw. przestępstw z nienawiści (hate crimes). Być może uzasadniona jest teza, iż przestępstwa o zabarwieniu rasistowskim tworzą swoistą odmianę hate crimes. W literaturze podkreśla się bowiem, że w przypadku wymienionej grupy przestępstw istotny jest symboliczny status ofiary, przy czym popełnianie przestępstw motywowanych nienawiścią służy budowie solidarności i wzmacnianiu tożsamości określonej grupy. ${ }^{43}$ Wydaje się, że popularność ideologii prawicowej wśród pseudokibiców wynika przede wszystkim z faktu, iż realizacja haseł programowych łączy się z gloryfikowaniem przemocy, która - jak już sygnalizowano - stanowi esencję działań podejmowanych przez chuliganów piłkarskich. ${ }^{44}$ Wyniki przeprowadzonego programu badawczego potwierdziły, iż również niektóre polskie grupy funkcjonujące w środowiskach pseudokibiców chętnie posługują się rasizmem jako uzasadnieniem dla stosowanej przemocy. ${ }^{45}$

41 Zob. szerzej materiały Stowarzyszenia Nigdy Więcej będące w posiadaniu Autora. Wymieniony podmiot monitoruje przejawy rasizmu i nazizmu, również w obszarze sportu, w szczególności piłki nożnej. Por. www. nigdywiecej.org

42 J. Szewczyk (red.), Bezpieczeństwo i zachowanie publiczności na imprezach sportowych, Warszawa 2001. Na potrzeby niniejszego artykułu korzystano ze zbioru dokumentów Rady Europy zawartych w cytowanym opracowaniu.

43 Zob. szerzej B. Hołyst, Wiktymologia, Warszawa 1997, s. 270 wraz z cytowaną tam literatura.

$44 \quad$ W związku z tym warto wskazać, że Stowarzyszenie Nigdy Więcej podczas monitoringu prasy zawierającej rasistowskie treści odnotowało następującą wypowiedź: Nie od dziś wiadomo, że kibice piłkarscy częstokroć stanowią aktyw różnych demonstracji. Sytuacja taka ma miejsce w przypadku grup funkcjonujących między innymi we Wrocławiu oraz w Gdańsku. 


\section{SUMmaRY}

The following article describes criminological aspects of stadium delinquency. This relatively new phenomenon in Poland constitutes a subject of interest in criminology. The problem of stadium delinquency has become particularly important also because of the Euro 2012 championship organized by Poland and Ukraine. The article shows certain traits of stadium delinquency among which we should point out : strong dynamic and evolution of this sector of crime, transfer of criminal activity outside sports facilities, connection of stadium delinquency with organized crime, especially the participation of hooligan groups in the drug trade among others. A significant aspect is also the fact that hooligans take part in so-called hatecrimes, which involves the diffusion of extremely right-wing attitude among certain groups of football hooligans. 